Female imperialism and nationalidentity

Imperial Order Daughters of the Empire KAT IE PICKLES

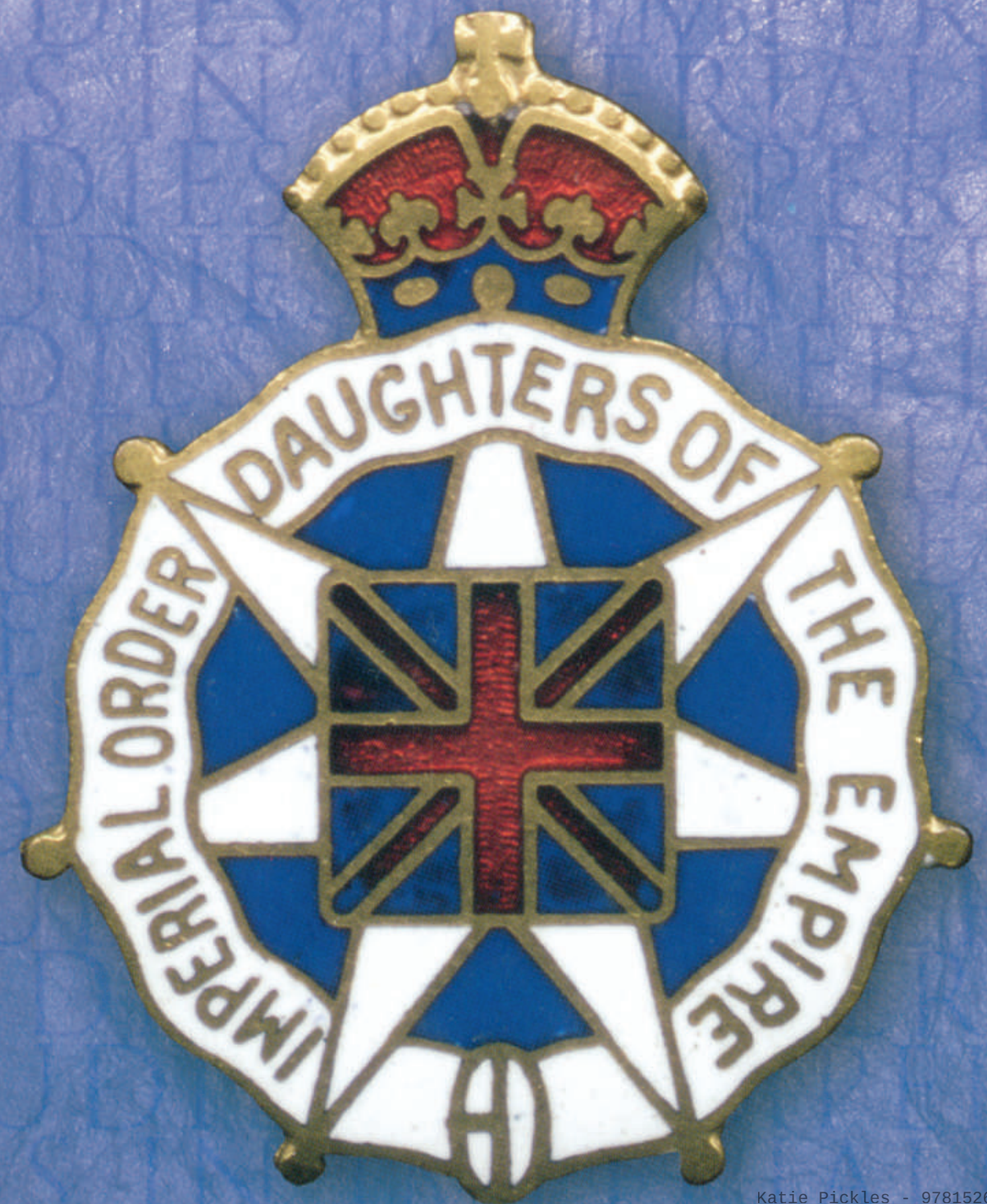




\section{IMPTUDIES IN-}

General editor John M. MacKenzie

When the 'Studies in Imperialism' series was founded by Professor John M. MacKenzie more than thirty years ago, emphasis was laid upon the conviction that 'imperialism as a cultural phenomenon had as significant an effect on the dominant as on the subordinate societies'. With well over a hundred titles now published, this remains the prime concern of the series. Cross-disciplinary work has indeed appeared covering the full spectrum of cultural phenomena, as well as examining aspects of gender and sex, frontiers and law, science and the environment, language and literature, migration and patriotic societies, and much else. Moreover, the series has always wished to present comparative work on European and American imperialism, and particularly welcomes the submission of books in these areas. The fascination with imperialism, in all its aspects, shows no sign of abating, and this series will continue to lead the way in encouraging the widest possible range of studies in the field. Studies in Imperialism is fully

organic in its development, always seeking to be at the cutting edge, responding to the latest interests of scholars and the needs of this everexpanding area of scholarship.

\section{Female imperialism and national identity}




\section{AVAILABLE IN THE SERIES}

Britain in China

Community, culture and colonialism, 1900-1949 Robert Bickers

New frontiers

Imperialism's new communities in East Asia 1842-1952 eds Robert Bickers and Christian Henriot

Western medicine as contested knowledge eds Andrew Cunningham and Bridie Andrews

The Arctic in the British imagination 1818-1914 Robert G. David Imperial cities

Landscape, display and identity eds Felix Driver and David Gilbert

Science and society in southern Africa Saul Dubow

Unfit for heroes

Reconstruction and soldier settlement in the Empire between the wars Kent Fedorowich

Emigration from Scotland between the wars Opportunity or exile? Marjory Harper Empire and sexuality

The British experience Ronald Hyam 'An Irish Empire?'

Aspects of Ireland and the British Empire ed. Keith Jeffery

Law, history, colonialism

The reach of empire eds Diane Kirkby and Catherine Coleborne

The South African War reappraised Donal Lowry

The empire of nature

Hunting, conservation and British imperialism John M. MacKenzie

Imperialism and popular culture ed. John M. MacKenzie

Propaganda and empire

The manipulation of British public opinion, 1880-1960 John M. MacKenzie

Gender and imperialism ed. Clare Midgley

Guardians of empire

The armed forces of the colonial powers, c. 1700-1964 eds David Omissi and David Killingray

Married to the empire

Gender, politics and imperialism in India, 1883-1947 Mary A. Procida

Imperialism and music

Britain 1876-1953 Jeffrey Richards

Colonial frontiers

Indigenous-European encounters in settler societies ed. Lynette Russell

Colonial masculinity

The 'manly Englishman' and the 'effeminate Bengali' Mrinalini Sinha

Jute and empire

The Calcutta jute wallahs and the landscapes of empire Gordon T. Stewart

The imperial game

Cricket, culture and society eds Brian Stoddart and Keith A. P Sandiford

The French Empire at war, 1940-45 Martin Thomas

British culture and the end of empire ed. Stuart Ward

Travellers in Africa

British travelogues, 1850-1900 Tim Youngs 


\title{
Female imperialism and national identity
}

\section{Imperial Order Daughters of The Empire}

Katie Pickles

\author{
MANCHESTER \\ UNIVERSITY PRESS \\ Manchester
}


Copyright $@$ Katie Pickles 2002

The right of Katie Pickles to be identified as the author of this work has been asserted by her in accordance with the Copyright, Designs and Patents Act 1988 .

Published by Manchester University Press

Altrincham Street, Manchester Ml 7JA, UK

www.manchesteruniversitypress.co.uk

British Library Cataloguing-in-Publication Data

A catalogue record for this book is available from the British Library

Library of Congress Cataloging-in-Publication Data

A catalog record for this book is available from the Library of Congress

ISBN 13: 9780719063916

First published in hardback 2002 by Manchester University Press

This paperback edition first published 2009

The publisher has no responsibility for the persistence or accuracy of URLs for any external or third-party internet websites referred to in this book, and does not guarantee that any content on such websites is, or will remain, accurate or appropriate. 